\section{Semarang State University Undergraduate LAWE SOCIETY REVIEW}

VOLUME 1 ISSUE 2, JULY 2021
ISSN (Print): 2807-8225 ISSN (Online): 2807-8683

History of Article

Submitted: December 2020

Revised: March 2021

Accepted: May 2021

\section{How to cite:}

Mafazi, S. S. (2021). Book Review "Glonggong", Junaidi Setiyono, Serambi Ilmu Semesta, Jakarta, ISBN 978-979-1275-48-4. Semarang State University Undergraduate Law and Society Review, 1(2), 191-202. https://doi.org/10.15294/lsr.v1i2.50617

(C) 2021 Authors. This work is licensed under a AttributionNonCommercial-ShareAlike 4.0 International (CC BY-NC-SA 4.0). All writings published in this journal are personal views of the authors and do not represent the views of this journal and the author's affiliated institutions.

\title{
Book Review "Glonggong", Junaidi Setiyono, Serambi Ilmu Semesta, Jakarta, ISBN 978-979- 1275-48-4
}

Sarwan Saukhi MAFAZI

Faculty of Law, Universitas Negeri Semarang

Jl. Taman Siswa, Sekaran, Gunungpati, Semarang Jawa Tengah, INDONESIA $\triangle$ sarwansaukhimafazi@gmail.com

\begin{abstract}
This book tells about a young man of noble descent who lived a simple life and lived among the poor during the struggle of Prince Antawirya or better known as Prince Diponegoro in Central Java. The Java War or De Java Oorlog (Netherlands) was a major and comprehensive war that lasted for five years (1825-1830) which took place in Java, between the Dutch colonial forces under the leadership of General De Kock against the indigenous population led by a Yogyakarta prince named Prince
\end{abstract}


Diponegoro. or who in this novel is referred to as Kangjeng Sultan Ngabdulkamid. This war was one of the biggest battles experienced by the Dutch during colonizing the archipelago. Where the victims of this war reached two hundred thousand more dead. This war involved the entire Java region, so this war is called the Java War. However, this book does not explain in depth about the Javanese war and also does not explain the life or struggle of a hero like Prince Diponegoro, but this book tells the history from another person's point of view about the personal life of a young Dipanegaran laskar follower and the social conditions of society in the past. the Javanese battle.

KEYWORDS. Glonggong; Book Review; War and Law

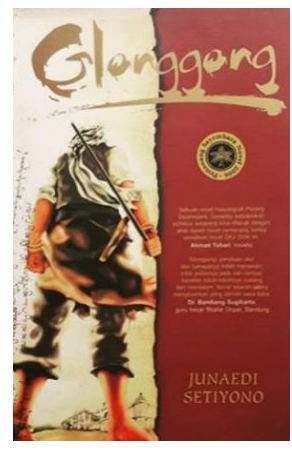

Title of Book

: Glonggong

Author

: Junaidi Setiyono

Year of Publication : 2007

Publisher

: Serambi Ilmu Semesta

City of Publisher

: Jakarta

Total of pages

: 291 pages

ISBN

: 978-979-1275-48-4

\section{GENERAL OVERVIEW OF THE BOOK}

This book talks about a young man of noble descent who lived a simple life and lived among the poor during the struggle of Prince Antawirya or better known as Prince Diponegoro in Central Java. The Java War or De Java Oorlog (Netherlands) was a major and comprehensive war that lasted for five years (1825-1830) which took place in Java, between the Dutch colonial forces under the leadership of General De Kock against the 
indigenous population led by a Yogyakarta prince named Prince Diponegoro. or who in this novel is referred to as Kangjeng Sultan Ngabdulkamid. This war was one of the biggest battles experienced by the Dutch during colonizing the archipelago. Where the victims of this war reached two hundred thousand more dead. This war involved the entire Java region, so this war is called the Java War. However, this book does not explain in depth about the Javanese war and also does not explain the life or struggle of a hero like Prince Diponegoro, but this book tells the history from another person's point of view about the personal life of a young Dipanegaran laskar follower and the social conditions of society in the past. the Javanese battle. The socio-cultural conditions of the people in the colonial era were very clear of social inequality, the court aristocrats were willing to side with the Company for their personal interests, while the small people had to accept their fate as helpless poor. The hard struggle within the group of Prince Aria Diponegara and his followers to crush the Dutch Company who also had to deal with Patih Danureja and his followers who were more in favor of the Dutch Company. The deceit and betrayal of war with the presence of religious figures who were once respected by the community has changed principles due to welfare and safety issues in dealing with the Company. The main character of this novel is Danukusuma, better known as Glonggong. Little Danukusuma grew up in the palace environment but often spent his days in the environment of the poor. The name Glonggong itself was obtained by little Danukusuma because of his skills in playing war using the glonggong sword. Glonggong is a pale green papaya leaf stalk. By Javanese children, the midrib of this papaya tree is used as a sword to play wars. While the name Glonggong he carried after he played war with Suta, his best friend. When he fell on the ground, someone he thought was Suta pulled him, and it turned out that he was not Suta but a son of the king named Bendara Raden Mas Antawijaya who later became known as Kangjeng Pangeran Aria Dipanegara. Kanjeng Prince Aria Dipanegara immediately greeted him and called him by the nickname "Glonggong". And since then 
Danukusuma was called Glonggong by his friends and that name continued to stick with him into adulthood. In Glonggong's blood flows blue blood, but his life is not as smooth as his other blue blooded friends. In the midst of the joys of childhood by playing and competing with glonggong, Glonggong is introduced to the harshness and rigors of life. His mother is a Raden Ayu from the Tegalreja area (the birthplace of Prince Diponegoro) who is married to Kiai Sena, a Jagabaya (security guard) from the Bagelen area. However, this marriage did not last long because his father disappeared during a rebellion led by Raden Rangga Prawidirja in 1810. At that time, Glonggong was still in the swing of his mother's shawl. He could not remember the face of his biological father who never returned home. His mother then remarried to Raden Suwanda who was a priyayi at that time. Raden Mas Suwanda who became his stepfather married Glonggong's mother after tricking him by telling him that Glonggong's biological father died in the rebellion. Glonggong lives with his mother and stepfather at the house of Raden Mas Suwanda named Dalem Suwandan, while his two brothers live with his uncle. Even though she is married, Mrs. Glonggong still thinks about Kiai Sena so that her mental condition is disturbed, she lives in her own world, every day she spends her time brooding in her room while singing macapat songs. Meanwhile, Raden Suwanda, Glonggong's stepfather, is busy with his priyayi. There is no rebuke that is harmonious like father and son. His stepfather is too foreign to glonggong. Glonggong felt the suffering of his mother who could only sing and daydream which affected his psyche. His mother's disturbed sanity made Raden Mas Suwanda expel his mother and himself from Dalem Suwandan and divorced them because there was already a new wife substitute. After they were expelled by Raden Mas Suwanda from Dalem Suwandan they were forced to live in a hut in the middle of the forest. Glonggong faithfully took care of his mother with all his heart, the days they spent together in a hut in the middle of the forest, until a fire tragedy devoured Glonggong's residence and took his mother's life. Now Glonggong has to live alone. Living alone makes him wander in search of 
his father and two siblings. In the midst of his confusion, Surya, his friend, Glonggong was kindheartedly appointed as a servant of Den Mas Pringgawinatan in ndalem Pringgawinatan. This priyayi secretly supports the struggle of Prince Aria Dipanegara, one of the sons of Hamengku Buwono III who chose to live apart from the luxurious environment of the palace because he did not agree with the actions of his relatives who had sold their pride as children of an independent nation. playing glonggong also worked as bodyguards for the court aristocrats. This work understands that aristocrats generally live in the luxury of wealth, thrones, and women who make their lives intoxicating. Until one day the stakes were installed by the Netherlands Company, a road will be made through the yard of Nyai Tegalreja or the tomb of Prince Dipanegara's grandmother. The stakes were then lifted by Prince Diponegoro, which made the atmosphere in Tegalrejo even more heated until the victims fell, Nyai Tegalreja castle burned, and with his followers, Prince Dipanegara left Tegalreja, headed for Selarong. The Javanese war finally broke out, splitting Javanese society into two poles. First, siding with Prince Dipanegara and against the Dutch Company. Second, sided with Patih Danureja (the palace) who conspired with the Dutch Company. Seeing this, Glonggong did not remain silent, he immediately joined the ranks of Prince Dipanegoro's soldiers. During his time as a soldier, he had never met directly with Prince Dipanegara. His meeting with Prince Dipanegara was when Prince Dipanegara was arrested by the Dutch with his fraudulent tactics. In a precarious situation, bloody riots, on the sidelines of Glonggong's efforts to find his brothers, Glonggong was thrown in prison. Here he met Ki Jayasurata who invited him to help Prince Dipanegara's struggle, replacing the task that had been carried out by Ki Sena and two of Glonggong's acquaintances. Glonggong is assigned to guard the treasure chest which will be exchanged for weapons belonging to Laskar Dipannegaran. In his task of guarding the treasure chests of the troop troops in the Semarang area to be exchanged for weapons, Glonggong was attacked by mules. He was injured quite badly. After recovering, he is 
confronted with the appearance of a person disguised as himself and killing the villagers. Besides that he is also determined to find back the treasure that was taken by the mules as his responsibility to the Prince.

Along with wandering in the context of carrying out his duties in the name of resistance against the colonialists of the Company, Glonggong also tried to find the whereabouts of his biological father and brothers and sisters. Reality collides with bitter and painful experiences. He is disappointed when he finds out that he has an older sister who turns out to be his own master's pet woman. Glonggong's journey to become a soldier becomes interesting because it involves many inner conflicts. How he deals with his family which is full of pain, how he controls his love, how he manages his heart when he finds out that his sister is a noble's pet. The war was getting more and more erratic, Prince Diponegoro's Kanjeng resistance was getting weaker, one by one his followers betrayed or surrendered to the Company. Until finally the Company persuaded the prince Diponegoro to negotiate in Magelang. In the midst of a crowd of hundreds of people watching the negotiations, Glonggong brought a candle of struggle treasures. He could not directly face Kanjeng Prince. Only from afar he could see until finally thousands of bullets scattered wildly. The atmosphere was chaotic, that's when the capture of Kanjeng Pangeran Diponegoro, the end of the Java War, and the last time Glonggong could see his lord.

Such was the mental cheating of the palace rulers during the Dutch Company era described by the author. Where a lot of cheating was done by the rulers and nobles of the palace to protect themselves in order to live safely in the pressure environment of the Dutch Company. They do not care about the welfare of their own people, they are more concerned with wealth, throne and women. Even more ironic is how the Dipanegaran troops themselves ended up frustrated because of the defeats they had suffered, so they eventually defected and looked for their own way. That was the social condition of the people during the Java war of 1825-1830. 
The socio-cultural conditions of the community in the novel Glonggong are very unique in exploring local wisdom which is an important force in society. In addition, the culture of the people in the palace environment causes women to have an unfavorable fate. Through the life story experienced by the mother of a young child named Glonggong, the author wants to give the reader an idea of the treatment of the nobles to a woman at that time. The character reversal in this novel is also very unique where the character who initially has a protagonist or antagonist character at the end of the story changes his character to the opposite. There are several shortcomings that may be weaknesses in this book, namely the description of the atmosphere of the Javanese war which is less clear, this makes it difficult for some readers who are still unfamiliar with the events of the Javanese war to understand and describe the atmosphere in the novel.

\section{LEGAL ISSUES ON THE BOOK}

\section{A. The Begaling of Assets belonging to the Laskar Dipanegaran by the Begal group}

The first legal issue in this novel is criminal acts in conditions of war. This act violates the law because it is clearly a form of crime. In the novel, it is told that when the situation was critical, there was a bloody riot, while Glonggong was trying to find his brothers and sisters, Glonggong was thrown into prison. Here he met Ki Jayasurata who invited him to help Prince Dipanegara's struggle, replacing the task that had been carried out by his father Ki Sena and two acquaintances with weapons belonging to Laskar Dipanegaran. In a task of guarding a treasure chest of soldiers in the area of Semarang to be exchanged for weapons, Glonggong was 
attacked by mules until he was seriously injured. How surprised Glonggong was when he found out that the mastermind behind this robbery was his friend, Danar. "The same thing happened to Kang Danar, my friend in Pringgawinatan, who had turned to lead a gang of gangsters. It turns out that this activity has been carried out for quite a long time. He had deceived Diponegara's group by robbing, looting and eating their rice. "Kang Danar?" my friend in Pringgawinatan smirked while stroking his thin, shiny sword. "You're now leading a gang of thugs?" "I've been mugging for a long time, you idiot! It's only because of the stupidity of the people of Diponegara that I can continue to rob while continuing to live a full life by eating their rice."

\section{B. Gender Injustice and Women's Rights}

Gender inequality and women's rights are legal issues that have become a culture among the royal men of the palace. This is a violation of the law because a woman must be treated well and women also have a human right to happiness in life. The women in the palace were only used as concubines according to the wishes of the nobles. Men in the palace environment have a myth that women are identical with tools to fulfill lust needs so that he is free to find the woman he wants. Men are superior and powerful so they are entitled to everything they want.

Other people around him were ignored, such as the behavior of Rama Suwanda, the wife of Glonggong's mother when he was with other women, as in the following quote, "When I walked towards the exit, in the foyer of the main house, Rama Suwanda was standing bare-chested, side by side with a woman with long, flowing hair that I had never seen before. Their clothes were disheveled, they seemed to have been worn hastily and carelessly." The women in the palace ultimately had the same fate. After a woman is taken as a wife, it will not be long before she will be left behind 
and look for another substitute, as experienced by Glonggong's mother. At that time, the priyayi of the palace, who had a clean appearance and always smelled good, had such a personality. As quoted as follows, "After the embarrassing incident in the Suwandan ndalem, I became quite close to the priyayi of the palace who always looked clean and fragrant. With his acquaintance Surya has told me something that I had never realized before how much mother suffered."

\section{Unhealthy Palace Political System}

An unhealthy political system is very clearly described in the novel Glonggong. This is related to the law when the denial of the truth is increasingly apparent. The political orientation developed by the leaders was the safety of themselves from the Dutch Company group above the safety of the people. What is the real life of the priyayi in the palace who choose to live comfortably by siding with the colonialists. Political interest trumps everything, even the public interest.

\section{Fraud by the Dutch Company Against Prince Diponegoro}

In the end of the story Prince Diponegoro was arrested by the Dutch Company for his fraudulent actions. This was a violation of the law because the fraudulent action was for the political interests of the Dutch Company. As in the quote, "Until finally the Company persuaded the prince Diponegoro to negotiate in Magelang. In the midst of a crowd of hundreds of people watching the negotiations, Glonggong brought a candle of struggle treasures. He could not directly face Kanjeng Prince. 
Only from afar he could see until finally thousands of bullets scattered wildly. The atmosphere was chaotic. That was the moment when Kanjeng Pangeran Diponegoro was captured, when the Java War ended, and the last time Glonggong could see his lord."

\section{WHAT WE LEARN AS LAW STUDENT FROM THE BOOK?}

The content of learning values and historical aspects contained in the novel Glonggong by Junaedi Setiyono emerged through several important events. Some events that later became part of history that cannot be denied. History is packaged in a fiction in order to produce a noble value and moral message. In addition, historical value can also provide information to readers about events or events in the past. Historical values that can be seen using social glasses in the novel Glonggong include the spirit of the nobles and ordinary people during the colonial period at that time, various kinds of original characteristics or characters of some nobles who finally came to the surface along with their political fraud, the legal system. which is inconsistent and tends to side with the nation's top brass, and then the last is the values of the struggle of the people who are very loyal in maintaining the nation's pride when the Dipanegara War will erupt.

From the contents of the story in the novel Glonggong by Junaidi Setiono, there are many values contained. Starting from historical values, social society, religion, culture, politics, law and others. The value that I want to explain is the value content of the political system during the Java war which is related to the law at that time. The lesson that we can take from the legal aspect in the novel is that a law is indispensable for its existence in society, because law is a tool used to regulate the behavior of society, both the people and leaders, all are equal in the eyes of the law. 
Likewise with politics in a country, the legal position is higher than the position of a politician. The law has a coercive and firm nature, if these characteristics are not applied in the law, what happens is human fraud and deception. Based on the content of the story in the novel Glonggong, the fraud and deceit were carried out by the Royal Palace nobles who were greedy and sided with the Company. The position that should be used to ensure the welfare of their people is used as a protector and access to seek safety from the Company, to live in luxury, play with women and other worldly luxuries. This happened because of a weak legal system, the cheating of high-ranking officials, and the ignorance of the people.

The conclusion is that the law in a country is important, it must exist, it must be coercive, it must be fair, and most importantly it also applies to state officials. Because if the law is weak then what will happen is political fraud, crime, human rights violations as in the novel Glonggong by Junaidi Setiyono. 


\section{Conflicting Interest Statement}

All authors declared that there is no potential conflict of interest on publishing this article.

\section{Funding}

None

Publishing Ethical and Originality Statement

All authors declared that this work is original and has never been published in any form and in any media, nor is it under consideration for publication in any journal, and all sources cited in this work refer to the basic standards of scientific citation. 